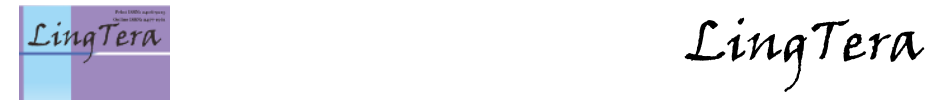

Volume 3 - Number 1, May 2016, (89-98)

Available online at: http://journal.uny.ac.id/index.php/litp

\title{
PENGEMBANGAN MEDIA MACROMEDIA FLASH UNTUK PEMBELAJARAN MEMBACA DAN MENULIS BAHASA INDONESIA DI SMA
}

\author{
Petrus Hariyanto $^{1}$ *, Suwardi Endraswara ${ }^{2}$ \\ ${ }^{1}$ Universitas Sanata Dharma Yogyakarta. Jalan Mrican Baru, Sleman, 55002, Indonesia. \\ ${ }^{2}$ Pendidikan Bahasa Jawa, Universitas Negeri Yogyakarta. Jalan Colombo No. 1, Karangmalang, \\ Yogyakarta 55281, Indonesia. \\ * Korespondensi Penulis. Email: p_hariyanto75@yahoo.com, Telp: +6281578847410
}

\begin{abstract}
Abstrak
Penelitian ini bertujuan untuk mengembangkan media Macromedia Flash untuk pembelajaran membaca dan menulis Bahasa Indonesia di SMA. Kegiatan ini merupakan penelitian dan pengembangan. Subjek uji cobanya siswa kelas X Semester 2 SMA Gama Yogyakarta. Penelitian dilakukan bulan Maret-Juni 2013. Pelaksanaannya melalui 10 tahap, dari analisis kebutuhan hingga uji lapangan. Data dikumpulkan melalui kuesioner. Data kuantitatif dianalisis dengan statistika deskriptif. Data berupa saran digunakan untuk merevisi produk yang dihasilkan. Hasil penelitian ini berupa media Macromedia Flash yang berkualitas untuk pembelajaran membaca dan menulis Bahasa Indonesia SMA. Produk tersebut mencakup teks, gambar, warna, dan suara; bersifat interaktif. Isinya berupa materi pembelajaran membaca dan menulis Bahasa Indonesia SMA Kelas X Semester 2, khususnya berkenaan dengan kompetensi merangkum tabel dan menulis paragraf argumentatif berdasarkan tabel. Ketiga pakar media mengategorikan baik. Ketiga pakar pembelajaran mengategorikan sangat baik. Kedua guru mengategorikan baik. Siswa dalam uji coba kelompok besar (lapangan) mengategorikan baik. Dapat disimpulkan bahwa media ini layak dipergunakan dalam pembelajaran di SMA.
\end{abstract}

Kata Kunci: media Macromedia Flash, pembelajaran membaca dan menulis, Bahasa Indonesia

\section{DEVELOPING MACROMEDIA FLASH MEDIA FOR LEARNING READING AND WRITING INDONESIAN IN SENIOR HIGH SCOOL}

\begin{abstract}
The purpose of this study is to develop Macromedia Flash media as media for learning to read and write Indonesian in senior high school. This is a research and development study. The subjects of the research were grade 10 students in the second semester of SMA Gama Yogyakarta. The research was conducted from March to June 2013. The implementation covered 10 stages, of analysis needs to field testing. Data were collected through questionnaires. Quantitative data was analyzed by applying descriptive statistics. Suggestions data are used to revise the product. The research is as a Macromedia Flash-quality which has a goal for learning to read and write Indonesian in senior high school. The developed product includes media components of text, images, colors, and sounds (music); they are interactive in nature. The content of the product are the materials of learning to read and write Indonesian subject for class X semester II Gama Senior High School Yogyakarta, especially in relation to summarizing tables and writing argumentative paragraph based on table. Three media experts categorize the product as good. Three teaching and learning experts categorize it as very good. Two teachers categorize it good. Students on the testing of a large group (field) to categorize good. It can be concluded that the media is feasible to use in the learning in senior high school.
\end{abstract}

Keywords: Macromedia Flash media, learning reading and writing, Indonesian

How to Cite: Hariyanto, P., \& Endraswara, S. (2016). Pengembangan media macromedia flash untuk pembelajaran membaca dan menulis bahasa indonesia di SMA. LingTera, 3(1), 89-98. doi:http://dx.doi.org/10.21831/lt.v3i1.8475

Permalink/DOI: http://dx.doi.org/10.21831/lt.v3i1.8475 


\section{LingTera, 3 (1), May 2016 - 90}

Petrus Hariyanto, Suwardi Endraswara

\section{PENDAHULUAN}

Tingkat literasi siswa Indonesia belum dapat dibanggakan. Skor rerata kemampuan membaca remaja Indonesia peringkat ke-58 dari 65 negara peserta studi PISA (Programme for International Student Assessment) 2009. Rerata nilai ujian nasional bahasa Indonesia SMP dan SMA menurun dari tahun ke tahun. Ironisnya, rerata nilai Bahasa Indonesia justru lebih rendah daripada rerata nilai bahasa Inggris; dan tidak sedikit siswa tidak lulus UN karena nilai Bahasa Indonesia jatuh (Koran Tempo, 2011, p. 3).

Keluhan perihal kemampuan menulis siswa sering terungkap, misalnya, Mahpudi (Community Organizer Paramedia Komunikatama) mengemukakan bahwa kemampuan menulis di kalangan siswa, terutama dalam bentuk pemikiran, mengalami penurunan (Lampung Post, 2010, p. 1).

Kekurangmampuan siswa kita dalam hal literasi juga terlihat dalam "List of countries by literacy rate" (Wales \& Sanger, 2013b, pp. 1 \& 7). Ini berupa daftar negara menurut tingkat literasi pada tahun 2011 (Departemen Statistik Individual dan Laporan Pembangunan Manusia PBB 2011).

Keadaan yang tidak dapat dibanggakan semacam ini sebenarnya sudah dilaporkan pada tahun-tahun sebelumnya. Hasil riset PISA tahun 2003 menunjukkan bahwa kemampuan literasi murid kita rendah (Suara Merdeka, 2008, p. 1), kemampuan literasi membaca siswa Indonesia di bawah standar internasional (Republika, 2009, p. 1). Mendikbud, Mohammad Nuh bahkan mengemukakan bahwa dalam ujian nasional (UN) tahun 2012 pun kebanyakan siswa jatuh pada nilai Bahasa Indonesia dan Matematika (Fajri, 2012, p. 1).

Seharusnya siswa setidaknya mencapai tingkat literasi fungsional. Istilah keaksaraan fungsional ini mengacu pada kemampuan dalam menggunakan keterampilan membaca dan menulis cukup baik untuk tujuan dan kegiatan yang biasanya memerlukan keaksaraan dalam kehidupan dewasa (Richards \& Schmidt, 2010, p. 345). Terbaca di sini bahwa upaya perbaikan pembelajaran membaca dan menulis di sekolah, khususnya dalam hal ini di SMA, masih perlu terus dilakukan. Berbagai langkah nyata perlu dikerjakan, antara lain dengan melaksanakan pengembangan media yang tepat untuk pembelajaran membaca dan menulis di SMA.

Sebuah perencanaan media didasarkan atas kebutuhan. Salah satu indikatornya adalah adanya kesenjangan, yaitu adanya ketidaksesuaian antara apa yang seharusnya atau apa yang diharapkan dengan apa yang terjadi. Dalam pembelajaran, yang dimaksud dengan kebutuhan adalah adanya kesenjangan antara kemampuan, keterampilan, dan sikap siswa yang kita inginkan dengan kemampuan, keterampilan, dan sikap siswa yang dimilikinya sekarang (Mustaji, 2012, p. 1).

Pada pihak lain, Richard Clark (Teknologi Pendidikan, 2012, p. 1) berdasarkan penelitiannya berpendapat bahwa media tidak berpengaruh terhadap kegiatan belajar. Menurutnya, media hanya merupakan kendaraan untuk kegiatan belajar (seperti halnya sebuah truk yang membawa sayuran, tidak memberikan nutrisi bagi tubuh kita), sedangkan yang berpengaruh terhadap kegiatan belajar adalah metode yang digunakan. Meskipun begitu, Clark setuju dengan pendapat bahwa media baru yang digunakan dalam kegiatan belajar akan berpengaruh terhadap kegiatan belajar seorang pembelajar, tetapi begitu pembelajar tersebut sudah terbiasa dengan media baru itu, maka pengaruh dari media tersebut sudah tidak ada lagi.

Aspek kebaruan dan kebelum terbiasaan siswa terhadap media yang digunakan dalam pembelajaran kiranya penting diperhatikan. Hal ini sesungguhnya sangat manusiawi. Manusia pada umumnya cenderung menjadi bosan, jenuh, terhadap sesuatu yang "itu-itu juga", yang "lagilagi begitu", monoton. Manusia memerlukan kebaruan, keberanekaan, dan kevariasian. Hal ini kiranya juga berlaku dalam pembelajaran membaca dan menulis. Kebaruan, keberanekaan, dan kevariasian media merupakan salah satu hal yang mungkin dapat menangkal kebosanan siswa dalam pembelajaran membaca dan menulis.

Macromedia Flash (kini disebut Adobe Flash) kiranya dapat digunakan dalam hal ini karena relatif masih baru bagi siswa SMA pada umumnya dan mungkin pula para siswa belum terbiasa dengannya. Macromedia Flash adalah platform multimedia dan perangkat lunak yang digunakan untuk animasi, game dan aplikasi pengayaan internet yang dapat dilihat, dimainkan, dan dijalankan di Adobe Flash Player. Flash sering digunakan untuk menambahkan video streaming atau audio player, iklan, dan konten multimedia interaktif untuk halaman web (Wales \& Sanger, 2013a, p. 1).

Ada berbagai kemungkinan peneyebab rendahnya kemampuan berbahasa Indonesia siswa kita. Antara lain ada yang menyatakan 


\section{LingTera, 3 (1), May 2016 - 91}

Petrus Hariyanto, Suwardi Endraswara

(Subkioke, 2012, p. 1) bahwa budaya kita memang tidak suka membaca dan susah menulis (di sini budaya dalam bahasa cakapan, berarti sesuatu yang sudah menjadi kebiasaan yang sudah sukar diubah). Benarkah begitu? Adakah kemungkinan lainnya?

Menurut Chaer (2009, pp. 251-263), masalah pembelajaran bahasa kedua, dalam hal ini juga mencakup pembelajaran membaca dan menulis, antara lain berkenaan dengan faktor motivasi, usia, penyajian formal, bahasa pertama, dan faktor lingkungan. Berkaitan dengan pemerolehan bahasa kedua, Brown (2008, pp. 13) mengemukakan bahwa antara lain yang memengaruhinya adalah faktor karakteristik pembelajar, faktor linguistik, faktor proses pembelajaran, faktor usia dan pemerolehan, faktor variabel instruksional, faktor konteks, dan faktor tujuan.

Persoalan pembelajaran bahasa juga dapat dilihat berdasarkan unsur yang perlu ada dalam silabus dan rencana pelaksanaan pembelajaran (RPP) antara lain sebagai berikut: mata pelajaran, satuan pendidikan, kelas dan semester, standar kompetensi, kompetensi dasar, materi pembelajaran, kegiatan pembelajaran, indikator, tujuan pembelajaran, penilaian, alokasi waktu, dan sumber belajar (BSNP, 2006, pp. 30-31; Mulyasa, 2006, pp. 239-241; Muslich, 2007, p. 47). Setiap hal itu memiliki kemungkinan mengandung berbagai permasalahan pembelajaran Bahasa Indonesia yang memerlukan pemecahan.

Secara relatif lebih lengkap dapatlah dikatakan bahwa kemungkinan sumber masalah rendahnya kemampuan berbahasa Indonesia siswa kita, khususnya dalam hal keaksaraan bahasa Indonesia, adalah berbagai hal berikut: guru; siswa; sarana; prasarana; kurikulum; metode pembelajaran. perangkat pembelajaran; kebijakan pemerintah; dan budaya masyarakat.

Karena berbagai keterbatasan, penelitian ini difokuskan pada masalah media, khususnya berkenaan dengan pengembangan media pembelajaran membaca dan menulis Bahasa Indonesia di SMA dengan menggunakan Macromedia Flash. Mengapa masalah pengembangan media, yang masih banyak diperdebatkan, yang dipilih? Hal ini sejalan dengan kesimpulan yang dikemukakan oleh Kozma (1994, via Rafleckt, 2010, p.2) bahwa kita harus berhenti memperdebatkan masalah pengaruh media dalam pembelajaran. Kita harus mulai memikirkan, dengan cara apa dan bagaimana agar kita dapat menggunakan kemampuan media guna memengaruhi pembelajaran berkenaan dengan siswa, tugas, dan situasi tertentu. Dengan begitu, kita akan memiliki lebih banyak kesempatan guna menemukan potensi media, dan kemudian menggunakannya sebagai fasilitas untuk meningkatkan kualitas pembelajaran yang kita laksanakan.

Media pembelajaran merupakan peralatan yang dapat digunakan atau tidak digunakan, bergantung pada tujuan instruksional, keadaan awal siswa yang aktual, materi pembelajaran, prosedur didaktis, dan bentuk pengelompokan siswa. Karena itu, ketersediaan sejumlah media pembelajaran akan memberikan keleluasaan alternatif kepada guru untuk memilih alat yang sesuai, sejalan dengan kekuatan dan kelemahan setiap media itu (Winkel, 2009, p. 321). Media pembelajaran membaca dan menulis bahasa Indonesia di SMA dengan menggunakan Macromedia Flash ini merupakan salah satu tambahan alternatif itu.

Mengingat keluasan ruang lingkup yang ada, dalam penelitian ini tidak semua masalah diteliti. Berdasarkan kemampuan, tenaga, dan waktu, masalah pokok dalam penelitian ini adalah berkenaan dengan pengembangan program Macromedia Flash untuk pembelajaran membaca dan menulis Bahasa Indonesia di SMA.

Secara umum, penelitian ini mempunyai tujuan mengembangkan program Macromedia Flash untuk pembelajaran membaca dan menulis di SMA. Program yang dikembangkan harus divalidasi terlebih dahulu untuk menentukan kualitas produk, baik dari aspek materi maupun dari aspek media pembelajaran. Validasi digunakan sebagai dasar pertimbangan merevisi program pembelajaran tersebut.

Spesifikasi produk yang dikembangkan dalam program Macromedia Flash 8 untuk pembelajaran membaca dan menulis Bahasa Indonesia di SMA ini memuat empat hal berikut ini: bahan penarik perhatian, misalnya warna, musik pengiring, sound, desain grafis, yang dapat menumbuhkan minat belajar dan meningkatkan pemahaman materi membaca dan menulis Bahasa Indonesia SMA; pendahuluan, yang meliputi petunjuk penggunaan program, identitas mata pelajaran, deskripsi singkat topik, standar kompetensi dan kompetensi dasar; materi serta contoh; dan soal pelatihan.

Program pembelajaran membaca dan menulis Bahasa Indonesia di SMA ini dapat dioperasikan dengan menggunakan komputer yang memiliki empat spesifikasi sebagai berikut: $R A M 128 \mathrm{Mb}$ (disarankan yang lebih tinggi); kapasitas hardisk kosong $81 \mathrm{Mb}$; VGA colour 
monitor; dan sistem operasi Microsoft Windows 98 SE, Windows 2000, Windows XP, atau sistem operasi Mac OS X 10.2.6.

Hasil pengembangan yang berupa produk pembelajaran ini antara lain dapat dimanfaatkan sebagai berikut ini: untuk sumber belajar siswa secara mandiri yang mampu menimbulkan motivasi; sebagai media bantu bagi guru untuk mentransfer materi membaca dan menulis Bahasa Indonesia di SMA, baik secara klasikal maupun individual; penambah koleksi program pembelajaran membaca dan menulis Bahasa Indonesia SMA berbantuan komputer dan berbasis kurikulum; serta sebagai titik tolak penelitian selanjutnya.

\section{METODE}

Penelitian ini termasuk jenis penelitian pengembangan, $\mathrm{R} \& \mathrm{D}$ (research and development) yang lazim dipergunakan untuk menghasilkan dan menguji validitas produk tertentu. $\mathrm{R}$ \& $\mathrm{D}$ digunakan dalam banyak bidang. Secara garis besar, menurut Torok, Borsi, \& Tecls (via Putra, 2012, p. 93) terdapat tiga model R \& D, yaitu linear, sirkular, dan random.

Berkaitan dengan model R \& D ini, Setyosari (2010, p. 207) mengemukakan bahwa model penelitian dan pengembangan pendidikan banyak ragamnya. Model yang paling dikenal dan dipakai secara luas adalah model Dich \& Carey. Model tersebut memiliki sepuluh langkah.

Sugiyono (2012, p. 298) menyampaikan sepuluh langkah penelitian dan pengembangan. Model pengembangan yang dipergunakan dalam penelitian dan pengembangan media Macromedia Flash untuk pembelajaran membaca dan menulis Bahasa Indonesia di SMA ini adalah model pengembangan yang didasari berbagai langkah penelitian tersebut. Pelaksanaannya melalui 10 tahap.

\section{Prosedur Pengembangan}

Langkah-langkah penelitian dan pengembangan media Macromedia Flash untuk pembelajaran membaca dan menulis Bahasa Indonesia di SMA tersebut adalah sebagai berikut: Analisis Kebutuhan (antara lain untuk menentukan materi pembelajaran dan media pembelajarannya yang perlu dikembangkan); Desain (untuk menentukan standar kompetensi dan materi yang akan dikembangkan); Produksi (dilaksanakan dengan menerapkan desain dan prinsip-prinsip penggunaan media Macromedia Flash sebagai salah satu jenis media pembelajaran berbasis komputer); Validasi I (dilakukan untuk memperoleh data kualitas media pembelajaran yang dikembangkan dan mendapatkan bahan masukan dalam rangka merevisi produk media); Revisi I (dilakukan setelah kegiatan validasi I selesai dilaksanakan); Validasi II (berbagai aspek media pembelajaran dinilai validitasnya dan diberi berbagai saran); Revisi II (masukan yang didapat dari kegiatan Validasi II dan dari hasil refleksi dimanfaatkan untuk memperbaiki produk media pembelajaran); Uji Kelompok Kecil (dilaksanakan oleh guru Bahasa Indonesia, melibatkan sebanyak 15 siswa dengan 9 berkas bahan); Revisi III (masukan dari para siswa, hasil kegiatan uji kelompok kecil, diolah dan dimanfaatkan untuk perbaikan media pembelajaran); dan $U j i$ Kelompok Besar (pelaksanannya oleh guru Bahasa Indonesia, pada 39 siswa dengan 39 berkas bahan).

\section{Uji Coba Produk}

Pengujicobaan produk (uji kelompok kecil dan uji kelompok besar/lapangan) dilakukan dengan tujuan untuk mengumpulkan data guna menentukan kualitas media Macromedia Flash untuk pembelajaran membaca dan menulis di SMA. Data yang diperoleh tersebut dipergunakan untuk memperbaiki dan menyempurnakan software media pembelajaran yang dihasilkan melalui penelitian ini. Dengan demikian, kualitas software yang dikembangkan benar-benar telah tervalidasi secara empiris.

Pembuatan desain uji coba merupakan tahapan penting yang perlu dilakukan agar software yang dihasilkan layak untuk digunakan. Pada tahap ini software yang dihasilkan akan dievaluasi melalui beberapa tahapan agar produk media yang dihasilkan ini benar-benar valid untuk digunakan dalam kegiatan pembelajaran. Untuk melakukan kegiatan evaluasi tersebut, dipergunakan instrumen kuesioner yang berisi item-item yang mencakup berbagai komponen dan indikator evaluasi media Macromedia Flash untuk pembelajaran membaca dan menulis di SMA.

Subjek uji coba untuk menguji produk media pembelajaran membaca dan menulis ini adalah para siswa SMA Gama Yogyakarta. Subjek uji coba dibatasi hanya siswa SMA Gama Yogyakarta antara lain karena media pembelajaran tersebut kiranya masih "baru" bagi siswa di lingkungan tersebut.

Data yang diperlukan dalam penelitian ini berasal dari pakar pembelajaran bahasa, pakar media, pemangku pengguna, dan para siswa. 


\section{Ling Tera, 3 (1), May 2016 - 93}

Petrus Hariyanto, Suwardi Endraswara

Jenis data yang dihimpun melalui penelitian ini berupa data kuantitatif dan data kualitatif. Data itu menunjukkan kualitas program media pembelajaran yang telah dihasilkan. Data itu dipergunakan sebagai masukan untuk melakukan revisi terhadap produk yang telah dihasilkan.

Data yang terkumpul berkenaan dengan kualitas media pembelajaran menurut pakar pembelajaran bahasa, kualitas media pembelajaran menurut pakar media, dan kualitas media pembelajaran menurut siswa.

Instrumen penelitian dikembangkan berdasarkan indikator penilaian kualitas pembelajaran. Ada tiga instrumen kuesioner yang dikembangkan: (1) kuesioner untuk menilai kualitas media pembelajaran yang ditujukan pada pakar pembelajaran bahasa dan pemangku pengguna, (2) kuesioner untuk menilai kualitas media pembelajaran yang ditujukan pada pakar media, dan (3) kuesioner untuk menilai kualitas media pembelajaran yang ditujukan pada siswa. Perhitungan penilaian kualitas media pembelajaran dilakukan dengan menggunakan Skala Likert. Dengan demikian, data kualitas media Macromedia Flash untuk pembelajaran membaca dan menulis di SMA ini akan mudah untuk dianalisis.

Data dianalisis dengan mengklasifikasikannya ke dalam dua kelompok, yaitu data kuantitatif dan data kualitatif. Data kualitatif berupa saran dan kritik yang diperoleh dari pakar pembelajaran bahasa, pakar media, guru, dan siswa digunakan untuk memperbaiki produk media ini.

Data kuantitatif dipergunakan untuk menilai kualitas media yang telah dihasilkan. Data diperoleh dari responden, yaitu pakar pembelajaran bahasa, pakar media, guru, dan siswa melalui kuesioner dengan skala Likert. Skala Likert dipilih karena mampu mengukur sikap, pendapat, atau persepsi seseorang atau sekelompok orang tentang kejadian atau gejala sosial.

Data yang diperoleh dianalisis dengan statistik deskriptif. Langkah-langkahnya meliputi (1) pengumpulan data kasar, (2) pemberian skor untuk analisis kuantitatif, dan (3) skor yang diperoleh melalui analisis dikonversikan menjadi nilai dengan skala lima. Penggunaan konversi skala lima ini memudahkan dalam penafsiran hasil kualitas media pembelajaran yang dikembangkan.

\section{HASIL DAN PEMBAHASAN}

\section{Analisis Kebutuhan}

Data analisis kebutuhan diperoleh melalui kuesioner yang berisi sepuluh pertanyaan. Berdasarkan jawabannya dapat ditarik empat kelompok kesimpulan. Kelompok simpulan pertama berkenaan dengan fasilitas media pembelajaran membaca dan menulis Bahasa Indonesia: fasilitas media pembelajaran membaca dan menulis Bahasa Indonesia belum memadai (64\% pendukung); dan media pembelajaran yang dominan digunakan adalah media tradisional (60\% pendukung).

Kelompok kesimpulan kedua berkaitan dengan urgensi pengembangan media pembelajaran membaca dan menulis Bahasa Indonesia: pengembangan media pembelajaran membaca dan menulis Bahasa Indonesia adalah urgen (100\% pendukung); pengembangan media pembelajaran membaca dan menulis Bahasa Indonesia perlu dilakukan (96\% pendukung); pengembangan media pembelajaran membaca dan menulis Bahasa Indonesia disetujui untuk dilaksanakan (100\% pendukung).

Kelompok kesimpulan ketiga berhubungan dengan pengembangan jenis media pembelajaran untuk pembelajaran membaca dan menulis Bahasa Indonesia: jenis media pembelajaran membaca dan menulis Bahasa Indonesia yang perlu dikembangkan berdasarkan indra yang digunakan adalah media audiovisual (70\% pendukung); jenis media pembelajaran membaca dan menulis Bahasa Indonesia yang perlu dikembangkan berdasarkan peralatan yang digunakan adalah media berbasis komputer $(71 \%$ pendukung).

Kelompok kesimpulan keempat berhubungan dengan bahan pengembangan jenis media pembelajaran untuk pembelajaran membaca dan menulis Bahasa Indonesia: standar kompetensi Bahasa Indonesia kelas X semester 2, "memahami ragam wacana tulis dengan membaca memindai" dan "mengungkapkan informasi melalui penulisan paragraf dan teks pidato" perlu dikembangkan media pembelajarannya dengan berbasis komputer (96\% pendukung); kompetensi dasar Bahasa Indonesia kelas $\mathrm{X}$ semester 2, "merangkum seluruh isi informasi dari suatu tabel dan atau grafik ke dalam beberapa kalimat dengan membaca memindai" dan "menulis suatu gagasan untuk mendukung suatu pendapat dalam bentuk paragraf arumentatif" perlu dikembangkan media pembelajarannya dengan berbasis komputer (91\% pendu- 


\section{Ling Tera, 3 (1), May 2016 - 94}

Petrus Hariyanto, Suwardi Endraswara

kung); topik materi membaca dan menulis Bahasa Indonesia kelas X semester 2 yang perlu dikembangkan dalam media pembelajarannya adalah pengetahuan dan teknologi (73\% pendukung).

\section{Deskripsi Produk Awal}

Hasilnya penggarapan produk awal ini berwujud instrumen penelitian yang berupa kisikisi dan lembar kuesioner analisis kebutuhan untuk pemangku pengguna serta untuk siswa; silabus, RPP, dan lembar kerja; kisi-kisi serta lembar kuesioner untuk pakar, pemangku pengguna, dan untuk siswa. Surat permohonan izin penelitian diperoleh dari Pascasarjana UNY disampaikan kepada SMA Gama Yogyakarta. Produk awal berupa flowchart dan storyboard serta CD rekaman wujud awal media Macromedia Flash untuk pembelajaran membaca dan menulis Bahasa Indonesia di SMA.

Produk media pembelajaran ini terutama dibuat dengan menggunakan program Macromedia Flash. Selain itu, produk ini juga menggunakan dua program pendukung, yaitu Corel Draw dan Gimp 3.4. Corel Draw, merupakan sebuah program untuk mendesain sebuah bentuk grafis yang berekstensi dengan vektor. Dalam kaitanya dengan pembuatan media ini, Corel Draw dipakai untuk membentuk panel-panel fungsi. Gimp 3.4, merupakan program dari Linux yang berfungsi untuk memberikan efekefek fotografi. Dalam kaitanya dengan pembuatan media ini, Gimp digunakan untuk memberikan efek-efek gradasi pada background dan beberapa simbol.

\section{Uji Coba dan Revisi Produk}

Konversi nilai skala lima dipergunakan untuk menentukan keseluruhan penilaian validasi data dari para pakar pembelajaran bahasa, pakar media, pemangku pengguna, dan dari siswa. Perhitungan penilaian kualitas media pembelajaran dengan dasar perhitungan skala lima sederhana

Validasi pakar pembelajaran bahasa tahap I (Produk Awal) mengungkapkan bahwa Pakar Pembelajaran Bahasa I memberikan rerata hitung 4. menunjukkan bahwa media pembelajaran yang dikembangkan tergolong baik. Pakar Pembelajaran Bahasa II menilainya dengan rerata hitung 4,86, menunjukkan kategori sangat baik. Pakar Pembelajaran Bahasa III memberikan penilaian 4,2, menunjukkan kategori baik. Apabila penilaian dari ketiga pakar pembelajaran dirata-rata, hasil validasi ketiga pakar pembelajaran bahasa sebesar 4,35, yang mengandung makna bahwa media yang dikembangkan berkategori sangat baik.

Validasi pakar pembelajaran bahasa tahap II (Pascarevisi) mengungkapkan bahwa data hasil validasi pakar pembelajaran bahasa tahap II memberikan masukan bahwa media yang dihasilkan sangat layak untuk diujicobakan di lapangan. Hal ini ditunjukkan dengan persentase nilai kualitas media pembelajaran dengan rerata hitung sebesar 4,66 dan berkategori sangat baik. Ketiga pakar juga mempertegas dengan rekomendasi bahwa program tersebut layak digunakan atau diujicobakan dengan tanpa revisi.

Revisi produk I media pembelajaran membaca dan menulis didasarkan pada hasil validasi pada tahap I (terhadap media produk awal). Revisi produk II media pembelajaran membaca dan menulis didasarkan pada hasil validasi tahap II (terhadap media pascarevisi). Pakar pembelajaran bahasa menyampaikan saran perbaikan untuk media pembelajaran yang dikembangkan setelah proses perevisian.

Dalam Revisi Produk Tahap I (Produk Awal), ada berbagai masukan. Karena berasal dari pakar pembelajaran bahasa, saran yang disampakan diharapkan juga berada dalam lingkup yang relevan dengan itu. Dalam kenyataan, masukan tidak selalu tegas tergolong dalam bidang tersebut.

Dalam revisi produk tahap II (pascarevisi), revisi produk media pembelajaran membaca dan menulis II didasarkan pada hasil validasi tahap II (terhadap media pascarevisi). Dalam hal ini, ternyata ketiga pakar pembelajaran bahasa tidak menyampaikan saran perbaikan untuk media pembelajaran yang dikembangkan setelah proses perevisian. Dengan demikian dapatlah ditafsirkan bahwa ketiga pakar telah melihat bahwa media pascarevisi tersebut telah memenuhi kelayakannya sebagai media pembelajaran membaca dan menulis bahasa Indonesia di SMA. Ketiganya menyatakan bahwa media tersebut telah layak digunakan atau diuji coba lapangan dengan tanpa revisi lagi.

Dalam validasi pakar media tahap I (Produk Awal), Pakar Media I menilai kualitas media berkategori baik dengan rerata hitung 3,73. Pakar Media III memberikan penilaian yang kebetulan tepat sama dengan penilaian Pakar media I. Pakar Media II menilai kualitas media dengan skor 3,6 berkategori baik. Dengan demikian, penilaian ketiga pakar media memiliki rerata hitung sebesar 3,7. 


\section{LingTera, 3 (1), May 2016 - 95}

Petrus Hariyanto, Suwardi Endraswara

Dalam validasi pakar media tahap II (Pascarevisi), data menunjukkan bahwa skor kualitas media pembelajaran pascarevisi yang dihasilkan meningkat, tetapi masih berkategori baik. Hal ini ditunjukkan dengan hasil rata-rata hitung penilaiannya sebesar 4,04. Dengan demikian, hasil validasi data ketiga pakar tersebut menunjukkan bahwa media pembelajaran pascarevisi yang dikembangkan layak untuk diujicobakan di lapangan. Hal ini juga dieksplisitkan dalam kesimpulan berupa rekomendasi ketiga pakar tersebut, bahwa media pembelajaran tersebut layak diuji coba lapangan dengan tanpa revisi.

Dalam revisi produk tahap I (Produk Awal), ada berbagai masukan terhadap media produk awal. Karena berasal dari pakar media, saran yang disampakan diharapkan juga berada dalam lingkup yang relevan dengan itu.

Dalam revisi produk tahap II (Pascarevisi), revisi produk media pembelajaran membaca dan menulis II didasarkan pada hasil validasi tahap II (terhadap media pascarevisi). Dalam hal ini, kegiatan dilakukan sebagai tanggapan terhadap berbagai masukan.

Dalam validasi pemangku pengguna tahap I (Produk Awal), hasil validasi penilaian kedua pemangku pengguna menunjukkan bahwa kualitas media pembelajaran yang dikembangkan dikategorikan baik, dengan rerata hitung 3,46.

Pemangku Pengguna I menilai kualitas media pembelajaran dengan rerata hitung sebesar 3,33. Pemangku Pengguna II memberikan penilaian kualitas media sebesar 3,6. Rerata hitung keduanya 3,46, berkategori baik. Dengan demikian dapatlah disimpulkan bahwa media pembelajaran yang dihasilkan menurut pemang$\mathrm{ku}$ pengguna dapat dimanfaatkankan dalam pembelajaran membaca dan menulis Bahasa Indonesia di kelas.

Dalam validasi pemangku pengguna tahap II (pascarevisi), media pembelajaran yang dikembangkan dinilai semakin berkualitas oleh kedua pemangku pengguna. Pemangku Pengguna I memberikan penilaian rerata 4,26, berkategori sangat baik. Rerata penilaian Pemangku Pengguna II menjadi 3,86, berkategori baik. Rerata hitungnya 4,06, berkategori baik.

Seperti yang telah dikemukakan, dasar yang digunakan untuk merevisi produk I (produk awal) media pembelajaran membaca dan menulis Bahasa Indonesia di SMA ini adalah hasil validasi pada tahap I (terhadap media produk awal). Revisi produk II media didasar- kan pada hasil validasi tahap II (terhadap media pascarevisi).

Berbagai masukan terhadap media produk awal telah disampaikan. Karena berasal dari pemangku pengguna, saran yang disampakan diharapkan juga berada dalam lingkup yang relevan dengan itu.

Revisi produk media pembelajaran membaca dan menulis II didasarkan pada hasil validasi tahap II (terhadap media pascarevisi). Dalam kaitan ini, revisi dibantu oleh masukan komentar dan saran dari Pemangku Pengguna I. Pemangku Pengguna II menyampaikan 5 nomor komentar dan saran.

Penelitian pengembangan media ini memerlukan pencermatan dari sekelompok kecil murid, dari lapangan, khususnya murid kelas $X$ SMA Gama Yogyakarta yang diharapkan menerima dan menggunakan media yang dikembangkan. Hal ini sejalan dengan kenyataan bahwa penelitian ini bermaksud mengembangkan media pembelajaran membaca dan menulis Bahasa Indonesia yang bertolak dari situasi di SMA Gama Yogyakarta.

Pengumpulan data validasi uji coba kelompok kecil dilakukan dengan menggunakan instrumen yang berupa kuesioner. Kuesioner tersebut dipergunakan untuk menilai kualitas media pembelajaran yang dihasilkan. Melalui kuesioner itu, siswa diminta memberikan penilaian kualitas media pembelajaran serta juga menuliskan komentar dan saran perbaikan.

Setelah hasil uji coba kelompok kecil dilakukan, diperoleh validasi data kualitas media pembelajaran yang dikembangkan. Data yang berasal dari 15 siswa dengan 9 berkas instrumen validasi tersebut menunjukkan bahwa kualitas media pembelajaran yang dikembangkan memiliki kualitas baik dengan rata-rata hitung penilaian sebesar 4,05. Dengan demikian dapat disimpulkan bahwa media pembelajaran yang dikembangkan dapat dipergunakan dalam pembelajaran membaca dan menulis Bahasa Indonesia.

Sebelum uji coba lapangan dilaksanakan, revisi produk yang berasal dari uji coba kelompok kecil dilakukan terlebih dahulu. Revisi produk didasarkan pada masukan yang diberikan oleh siswa yang menjadi responden pada uji coba kelompok kecil yang dimaksud. Revisi produk diperoleh dari tanggapan yang disampaikan siswa dalam kuesioner.

Tidak semua siswa peserta uji kelompok kecil menuliskan tanggapan. Didapatkan 9 tanggapan: 3 tanggapan dari perseorangan dan 6 tanggapan dari kelompok berdua. Siswa peserta 


\section{LingTera, 3 (1), May 2016 - 96}

Petrus Hariyanto, Suwardi Endraswara

uji kelompok kecil diberi kebebasan dalam mengemukakan pendapat sebagai tanggapan. Karena itu, terdapat beragam tanggapan.

Pengumpulan data validasi uji coba kelompok besar dilakukan dengan menggunakan instrumen yang berupa kuesioner. Kuesioner tersebut dipergunakan untuk menilai kualitas media pembelajaran yang dihasilkan.

Berdasarkan data, hasil penilaian menunjukkan bahwa kualitas media pembelajaran yang dikembangkan berkategori baik. Hal ini dinyatakan oleh rerata hitung penilaian sebesar 3,84. Skor penilaian ini menunjukkan bahwa media pembelajaran yang dikembangkan dapat dipergunakan dalam pembelajaran membaca dan menulis Bahasa Indonesia di SMA.

Hasil akhir penilaian berupa rerata hitung keseluruhan sebesar 3,84 dapat diartikan bahwa media pembelajaran yang dikembangkan ini layak dipergunakan dalam pembelajaran membaca dan menulis bahasa Indonesia.

Aspek yang dinilai sangat baik adalah aspek nomor 2 (Kemudahan penggunaan media ini mempermudah pelaksanaan pembelajaran) dan nomor 10 (Media pembelajaran yang dikembangkan ini mengandung aspek kebaruan bagi siswa kelas kami pada umumnya).

Aspek yang dinilai berkategori baik adalah aspek nomor 1, 3, 4, 7, 8 dan 9. Sedang aspek yang dinilai berkategori cukup adalah aspek media bernomor 5 (Soal evaluasi/pelatihan mudah dipahami dan sesuai dengan media yang dikembangkan) dan nomor 6 (Evaluasi/pelatihan dapat memberikan masukan tentang pemahaman saya perihal merangkum tabel dan menulis paragraf argumentatif). Masukan tersebut sungguh penting diperhatikan.

Revisi produk dilakukan dengan memanfaatkan masukan yang diperoleh dari para siswa uji coba lapangan/kelompok besar. Dari 39 siswa peserta uji kelompok besar terdapat 17 siswa yang menuliskan catatan tanggapan. Sebagian besar cenderung berupa dukungan positif terhadap produk media pembelajaran yang dikembangkan. Situasi isi tanggapan tertulis para siswa uji kelompok besar ini ternyata tidak jauh berbeda dengan situasi isi tanggapan tertulis para siswa uji kelompok kecil.

\section{SIMPULAN DAN SARAN}

\section{Simpulan}

Penelitian ini berhasil mengembangkan media Macromedia Flash untuk pembelajaran membaca dan menulis Bahasa Indonesia di
SMA: mencakup komponen media teks, gambar, warna, dan suara (musik); bersifat interaktif; isinya berupa materi pembelajaran membaca dan menulis Bahasa Indonesia SMA Kelas X Semester 2, khususnya berkenaan dengan kompetensi merangkum tabel dan menulis paragraf argumentatif berdasarkan tabel.

Kualitas komponen pembelajaran media menurut pakar pembelajaran bahasa dalam tahap I: sangat baik dengan rerata hitung sebesar 4,35; dalam tahap II: sangat baik dengan rerata hitung sebesar 4,66, media layak dipergunakan. Kualitas tampilan dan penyajian media menurut pakar media dalam tahap I: baik dengan rerata hitung sebesar 3,7; dalam tahap II: baik dengan rerata hitung sebesar 4,04, media layak dipergunakan. Kualitas komponen pembelajaran media menurut pemangku pengguna dalam tahap I: baik dengan rerata hitung sebesar 3,46; dalam tahap II: baik dengan rerata hitung sebesar 4,06, media layak dipergunakan. Kualitas media menurut siswa dalam uji coba kelompok kecil: baik dengan rerata hitung sebesar 4,05; dalam uji coba kelompok besar: baik dengan rerata hitung sebesar 3,84, media layak dipergunakan.

\section{Saran}

\section{Pemanfaatan media}

Produk ini dapat dimanfaatkan sebagai salah satu alternatif media pembelajaran membaca dan menulis Bahasa Indonesia, khususnya di SMA Gama Yogyakarta. Media pembelajaran ini juga dapat dimanfaatkan oleh siapa saja yang memerlukannya. Media ini dapat dimanfaatkan baik dalam program kurikuler (bersangkutan dengan kurikulum), kokurikuler (rangkaian kegiatan kesiswaan yang berlangsung di sekolah), intrakurikuler (kegiatan siswa di sekolah atau yang sesuai atau sejalan dengan komponen kurikulum), maupun dalam program ekstrakurikuler (berada di luar program yang tertulis di dalam kurikulum, seperti pelatihan kepemimpinan, jurnalistik, dan pembinaan siswa).

\section{Diseminasi Media}

Perlu dilakukan penggandaan media ini agar guru Bahasa Indonesia dan siswa, khususnya di SMA Gama Yogyakarta, dapat memilikinya. Media ini perlu disebarluaskan kepada umum, terutama pada para guru Bahasa Indonesia di SMA. Media ini perlu tersedia di perpustakaan, khususnya di SMA Gama Yogyakarta. 


\section{LingTera, 3 (1), May 2016 - 97}

Petrus Hariyanto, Suwardi Endraswara

Pengembangan Media

Mengingat keterbatasan media ini, penyempurnaan masih perlu dilakukan untuk mengatasi kekurangan dan menyesuaikannya dengan situasi yang ada (misalnya perbaikan desain, teks, dan soal). Media ini memerlukan penelitian lanjutan, yaitu penilaian terhadap media ini dengan menggunakan metode eksperimen yang melibatkan kelompok kontrol. Media ini memerlukan penelitian lanjutan lainnya, yaitu uji coba penggunaannya dalam pembelajaran di sekolah lain. Pelaksanaan penelitian di sekolah dalam semester gasal akan lebih kondusif daripada dalam semester genap. Media pembelajaran berbasis komputer ini dapat pula dikembangkan untuk pembelajaran keterampilan berbahasa Indonesia lainnya.

\section{DAFTAR PUSTAKA}

Brown, H. D. (2008). Prinsip pembelajaran dan pengajaran bahasa. Terjemahan dari edisi V oleh Noor Cholis dan Yusi Avianto Pareanom. Jakarta: Kedutaan Besar Amerika.

BSNP. (2006). Panduan penyusunan kurikulum tingkat satuan pendidikan jenjang pendidikan dasar dan menengah. Jakarta: Badan Standar Nasional Pendidikan.

Chaer, A. (2009). Psikolinguistik: kajian teoretik. Cetakan II. Jakarta: Rineka Cipta.

Fajri, A.N. (2012). "Ujian nasional sma: nilai siswa jatuh di bidang bahasa Indonesia \& matematika". Diambil pada tanggal 2811-2013 dari http://www.bisnis. com/articles/ujian-nasional-sma-nilaisiswa-jatuh-di-bidang-bahasa-indonesiaand-matematika

Koran Tempo. (2011). "Kemampuan baca orang Indonesia payah". Sabtu, 22 Oktober. Diambil pada tanggal 22-10-2013 dari http://www.islamic- bookfair.com/opinipilihan/263-kemampuan-baca-orangindonesia-payah.html.

Lampung Post. (2010). "Kemampuan menulis siswa lemah". Selasa, 27 Juli. Diambil pada tanggal 22-10-2013 dari http://ulunlampung.blogspot.com/2010/07 /kemampuan-menulis-siswa-lemah.html.

Mulyasa, E. (2006). Kurikulum tingkat satuan pendidikan: Sebuah panduan praktis. Bandung: Remaja Rosdakarya.
Muslich, M. (2007). KTSP (kurikulum tingkat satuan pendidikan): Dasar pemahaman dan pengembangan. Jakarta: Bumi Aksara.

Mustaji. (2012). "Pengembangan media pembelajaran: diklat standar alat dan media pembelajaran untuk SMA". Diambil pada tanggal 13 Juli 2012 dari http://www.tp.ac.id/site/pengembanganmedia-pembelajarandiklat-standar-alatdan-media-pembelajaran-untuk-sma.

Putra, N. (2012). Research \& development, penelitian dan pengembangan: suatu pengantar. Cetakan II. Jakarta: Raja Grafindo Persada.

Rafleckt. (2010). "How media and technology influence learning". Diambil pada tanggal 22-10-2013 dari http://rafleckt.wordpress.com/2010/04/23/ how-media-and-technology-influencelearning/

Republika. (2009). "Kemampuan siswa Indonesia di bawah standar internasional". Diambil pada tanggal 2210-2013 dari http://subkioke.wordpress.com/2009/ 11/02/kemampuan-siswaindonesia-dibawah-standar-internasional/

Richards, J.C., \& Schmidt, R. (2010). Longman dictionary of language teaching and applied linguistics. Edisi IV. London: Pearson Education Limited.

Setyosari, P. (2010). Metode penelitian pendidikan dan pengembangan.Jakarta: Prenada Media Group.

Suara Merdeka. (2008). "Kemampuan literasi siswa rendah". Diambil pada tanggal 2210-2013 dari http://suaramerdeka.com/v1/index.php/rea d/cetak/2008/12/23/44613/KemampuanLiterasi-Siswa-Rendah-

Subkioke. (2012). "Budaya kita, tidak suka membaca dan susah menulis". Diambil pada tanggal 22-10-2013 dari http://subkioke.wordpress.com/2012/06/1 1/ budaya-kita-tidak-suka-membaca-

Sugiyono. (2012). Metode penelitian kuantitatif, kualitatif, dan $r$ \& $d$. Cetakan XVI. Bandung: Alfabeta. 


\section{LingTera, 3 (1), May 2016 - 98}

Petrus Hariyanto, Suwardi Endraswara

Teknologi Pendidikan. (2012). "Media will never influence learning: the theories of richard clark". Diambil pada tanggal 2310-2013 dari http://www. tp.ac.id/site/media-will-never-influencelearning-the theories-of-richard-clark.

Wales, J. \& Sanger, L. (Eds). (2013a). "Adobe flash". Diambil pada tanggal 23-10-2013 dari http:// en.wikipedia.org/wiki/Adobe_Flash.
Wales, J. \& Sanger, L. (Eds). (2013b). "List of countries by literacy rate". Diambil pada tanggal 23-10-2013 dari http://en.wikipedia.org/wiki/List_of_coun tries_by_literacy_rate.

Winkel, W.S. (2009). Psikologi pengajaran. Cetakan X. Yogyakarta: Media Abadi. 